\section{Elements of Burial Equipment}

The El-Zuma tumuli yielded a wealth of burial equipment made of various raw materials. Unfortunately, many of these items had been badly damaged by environmental conditions and displaced by robber activity (see Volume I, Chapters 3 and 5). Among the numerous objects made of composite materials (e.g. metal and wood, or metal and bone), only the metal parts were preserved in reasonable condition. Most organic materials, such as wood and leather, survived solely in residual form. As was mentioned earlier, a large proportion of the objects preserved at El-Zuma are metal artefacts, among them items of burial equipment represented by nails and fittings, and miscellaneous objects. A lot of the metal finds are so fragmentary that it is not possible to determine their function.

The term "elements of burial equipment" is used in this publication to describe artefacts such as bier parts and different kinds of boxes found in graves at various sites of the post-Meroitic period (Emery and Kirwan 1938, 278-282; Edwards 1998, 112-123; 1994, 172-174, Pl. XXIX.1). Such finds usually accompanied the privileged class, and not only in the post-Meroitic period, but at least since Napatan times, or even earlier, as evidenced by the Tombos cemetery (Smith 2008, 103-109) (see also Figs 1 and 3, at the end of this volume). After the fall of Meroe, the royal graves at the cemeteries in Ballana and Qustul were the most important archaeological sites where elements of fine-quality burial equipment, such as beds, large and small chests, tables, and chairs, were discovered (Emery and Kirwan 1938, 123-124, 278-282, 383-384, Figs 95-98, Pl. 109). Boxes also appeared in burials at the Karanog cemetery (Woolley and Randall-MacIver 1910, 32-33, 44, Pls 21-22, 24), while funeral beds were found in elite graves at El-Hobagi (Lenoble 2018, 195-197, Fig. 78) and Qasr Ibrim (Emery and Kirwan 1938, Fig. 1). The El-Zuma cemetery is also thought to have been an elite burial ground featuring equipment of this type.

Two main categories of funeral equipment were recorded in the El-Zuma tumuli: biers on which the body was placed, and containers in the form of chests or boxes of unspecified sizes. No complete biers or boxes were excavated at the site; only their metal parts, such as nails and fittings, have survived.

\section{Elements of Burial Equipment: Description of the Material}

\subsection{State of Preservation}

The biers and boxes posed a number of problems. Their poor state of preservation (they were represented mainly by nails and metal fittings) meant that there was a lack of information about the shape and size of these artefacts, and their identification was only possible through analogies. The wooden components of these burial furnishings survived in fragmentary form [see Fig. 18.6]. Sometimes only traces of different soil colours recorded in the graves could be regarded as evidence of organic materials used in these constructions. However, this evidence can often be misleading and relate to completely different objects (pole arms, leatherwork, fabrics, and even the soft tissues of the body), or attest to the activity of pests that got inside the grave after burial. At El-Zuma it was only the remains of metal fittings and nails that indicated that a bed or box had been present, although most of these items were not found in their original contexts. It was only in a few cases, when bier remains were found in undisturbed contexts, that they could be positively identified (tumulus 6 , see Table 17.1).

Another problem is the preservation of the metal elements. Artefacts made of iron are very susceptible to corrosion. Therefore, most of the fittings and nails from the bier survive in poor condition, usually preventing their complete reconstruction. The state of these items was further exacerbated by the destructive effects of robber activity. In targeting the body to remove the jewellery that adorned it (see Chapters $4-6$, this volume), the robbers also damaged the funeral bed. Boxes and chests that may have contained valuable items could also have been destroyed during looting. No chests or boxes were found in any of the graves at El-Zuma.

\section{$1.2 \quad$ Nails}

Nails from El-Zuma come in very different sizes. The largest nails, such as Z24/54.1 [Cat. 37], are about $1.3 \mathrm{~cm}$ in cross-section with a head that is more than twice as large, measuring about $2.6 \mathrm{~cm}$ in cross-section. The longest preserved fragments of nails with a cross-section of $1.3 \mathrm{~cm}$, among them $\mathrm{Z}_{24} / 5^{2}$ [Cat. 3o, Fr. 3], are approximately $9 \mathrm{~cm}$ long. The most common variety are small nails with diameters of $0.6-0.9 \mathrm{~cm}$. The smallest nails were found 
TABLE 17.1 Distribution of bed-frame fittings and nails in tombs at El-Zuma

\begin{tabular}{|c|c|c|c|c|}
\hline $\begin{array}{l}\text { Tumulus } \\
\text { no. }\end{array}$ & $\begin{array}{l}\text { Type of } \\
\text { tumulus }\end{array}$ & Sex & $\begin{array}{l}\text { Bed frame fittings and nail } \\
\text { fragments }\end{array}$ & Context \\
\hline T.1 & I & - & 17 & Chamber 1 \\
\hline T.2 & I & - & - & - \\
\hline T.3 & I & - & - & - \\
\hline T.4 & I & - & 89 & Tunnel \\
\hline $\mathrm{T} .5$ & I & $\mathrm{M}(?)$ & 6 & Chamber 1 and tunnel \\
\hline T.6 & I & - & left in chamber, not examined & Chamber 1 \\
\hline $\mathrm{T} .7$ & I & $\mathrm{M}(?)$ & left in chamber, not examined & Chamber 1 \\
\hline T.8 & I & $\mathrm{F}(?)$ & 3 & Chamber 1 and shaft (near blocking wall) \\
\hline T.9 & II & $\mathrm{M}(? ?)$ & 14 & Chamber 1 and shaft (near blocking wall) \\
\hline T.11 & II & $?$ & 5 & Chamber 1 \\
\hline T.12 & II & - & - & - \\
\hline T.13 & II & $\mathrm{M}(?)$ & 14 & Shaft (near blocking wall) \\
\hline T.14 & II & $\mathrm{F}(?)$ & 3 & Chamber 1 \\
\hline T.15 & II & $\mathrm{F}(?)$ & 24 & Chamber 1 and shaft (near blocking wall) \\
\hline T.16 & II & $\mathrm{M}(? ?)$ & 31 & Chamber 1 \\
\hline T.23 & II & - & - & - \\
\hline T.24 & II & $\mathrm{F}(?)$ & $5^{8}$ & Chamber 1 \\
\hline T.25 & II & $\mathrm{F}$ & 2 & Chamber 1 \\
\hline T.26 & II & $\mathrm{F}$ & 8 & Chamber 1 \\
\hline T.10 & III & $\mathrm{M}$ & - & - \\
\hline T.17 & III & M & - & - \\
\hline T.18 & III & $\mathrm{F}(?)$ & - & - \\
\hline T.19 & III & $\mathrm{M}(?)$ & - & - \\
\hline T.2O & III & $\mathrm{M}(? ?)$ & - & - \\
\hline T.21 & III & $\mathrm{M}$ & - & - \\
\hline T.22 & III & $\mathrm{M}$ & - & - \\
\hline T.27 & III & $\mathrm{M}$ & - & - \\
\hline T.28 & III & $\mathrm{F}$ & - & - \\
\hline Total & & & 274 & - \\
\hline
\end{tabular}

PRODUCED BY Ł. ZIELIŃSKI

in tumulus 4 together with elements of decorated silver fittings featuring scarab and palm motifs (see Chapter 5 , Fig. 5.15, Z4/95, this volume). These nails are also made of silver; they are $1.2 \mathrm{~cm}$ long with a diameter of $0.2 \mathrm{~cm}$, and they resemble shoe nails (like the silver nail from group $\mathrm{Z} 4 / 93)$. Other finds in this category include copper clamps, about $1 \mathrm{~cm}$ long (reminiscent of modern staples), which were used instead of nails in conjunction with thin copper fittings, as illustrated by fragment $\mathrm{Z}_{7} / 5$ [Cat. 54]. In many cases, small pieces of wood that were in direct contact with nails (and also several staples, such as $\mathrm{Z}_{7} / 5$ ) have been preserved due to the action of oxides. Almost all nails, with the exception of clamps and nails used with copper fittings, were made of iron. All of them, even the sil- ver ones, have a characteristic square cross-section, gradually tapering towards the tip, and a head which is convex in the middle and has sharp edges. This is due to the fact that they were forged, which makes them very easy to distinguish from modern nails, which are round in cross-section. A distinctive feature of nails that were used to attach bed frame fittings is that they are thicker and shorter than the nails present in the bed frame by themselves. The nails in the copper fittings, e.g. $\mathrm{Z}_{7} / 19.2$ [Cat. $5^{\mathrm{O}}$ ], were probably similar in size to the preserved silver nails, which is easy to judge from the extant fragments and nail holes. Nails from other sites are mostly not described at all, but the elements of a bed frame from El-Hobagi were made of iron (Lenoble 2018, 195-197, Fig. 78). Many containers 
(boxes) and beds were found at the royal cemeteries in Ballana and Qustul (Emery and Kirwan 1938, 123-124, 278282, 383-384, Figs 95-98, Pl. 109), but no detailed information is given about nails. The same applies to finds from Karanog (Woolley and Randall-MacIver 1910, 32-33, 44, Pls 21-22, 24) and Tombos (Smith 2008, 103-109). We have no detailed description of nails or fittings of any kind from these sites. Anthony J. Mills provides some drawings and gives the lengths of two nails from Qasr Ibrim (Mills 1982, 48, 59, Pls LV 32.1, LXI 121.12). These nails were made of iron and measure $6.1 \mathrm{~cm}$ and $10.6 \mathrm{~cm}$ long respectively. They are of similar shape to the nails found at the El-Zuma cemetery (Mills 1982, Pls LV 32.1, Pl. LXI 121.12).

\subsection{Bed Parts and Fittings}

The fittings can be divided into two groups: iron ones, which were in the overwhelming majority, and those made of other metals, such as copper or silver. Some copper and silver fittings were decorated in repoussé with different patterns (for pattern descriptions see below). Most of the iron fittings came from funeral beds, and they are relatively easy to recognize thanks to their characteristic features. Bed fittings were usually made of a longitudinal iron strip widening at the ends through which nails were driven. These fittings are usually bent at an angle of about 90 degrees because they were attached to the corners of the bed from the outside. Fitting Z11/33 [Cat. 41] suggests that similar fittings were also used on the inner corners of the beds, but this is the only inner fitting found at El-Zuma.

The bed fittings were usually $2.5 \mathrm{~cm}$ to $3 \mathrm{~cm}$ wide, varying in thickness from $0.2 \mathrm{~cm}$ to $0.4 \mathrm{~cm}$. Typical bed fittings include Z16/33 [Cat. 46], Z24/54.1 [Cat. 37] and Z26/8 [Cat. 47]. Width and thickness are diagnostic features of bed frame fittings from El-Zuma. These dimensions are far more telling than length, which is often difficult to assess because the fittings are so fragmented. Another very characteristic feature seen on the external face of fittings are textile fragments preserved by oxides in the linen weave that originally covered the bed; one such example is $\mathrm{Z}_{24} / 54.1$. Wood impressions are always noted on the inner face. These impressions can provide some clues about the wooden bed frame. In several cases they reveal that there was a $0.2 \mathrm{~cm}$ gap between the boards that made up the frame, which may indicate the use of expansion joints [see Fig. 17.7]. Gaps of this size are also evident on some nails found in isolation. The ends of some nails that had been driven through a board were bent at 9o degrees, like Z24/9 [Cat. 28, Fr. 3]. The impressions sometimes indicate the thickness of the boards used, which in several cases was about $2 \mathrm{~cm}$. Unfortunately, their width is not so easy to determine. However, based on the better-preserved out- lines of the beds, as well as analogies with traditional beds used in Sudan to this day, we can identify a few important features. The El-Zuma beds were frame-built, rectangular constructions, long and wide enough for a man to lie on (Lenoble 2018, 195-197, Fig. 78; Emery and Kirwan 1938, $123-124,146,152$ ). Each corner of the frame was connected on top, so at least four fittings were used on each bed. Sometimes as many as eight may have been used, given the discovery of inner corner fittings, like the aforementioned $\mathrm{Z} 11 / 33$. The fact that in several instances mud bricks were found at the corners of the frame suggests that, unlike ordinary beds, those from El-Zuma had no legs, as demonstrated by the remains of the bed in tumulus 7 (Mahmoud El-Tayeb, Skowrońska, and Czyżewska 2016, 123-125, Pl. 33) and tumulus 6 . However, this cannot be stated with one hundred percent certainty in all cases due to the state of preservation of the evidence.

The presence of biers in graves of this period is not a very common occurrence, although similar objects have been recorded at other contemporaneous sites, like Qasr Ibrim (Emery and Kirwan 1938, Fig. 1), El-Hobagi (Lenoble 2018, 195-197) and Ballana (Emery and Kirwan 1938, 123$124,146,152)$. Some bed remains were also found at Tombos (Smith 2008, 103-109), but in tombs dated to the Napatan period, the Third Intermediate Period, and the Eighteenth Dynasty. The presence of a bed is a distinctive feature of Nubian burial practice (Smith 2008, 105) and has a long tradition. In El-Zuma alone, the remains of funerary beds were found in 15 of the 28 examined graves [see Table 17.1].

\subsection{Boxes}

Fragments of other distinctive metalwork were also found in some tumuli. These were mainly fittings made of copper and silver, some of them decorated, but also small nails and iron fittings. A large accumulation of elements of this type occurred in tumuli 4 and 7 . Mysterious small fragments of sheet copper, rods and some unidentified iron elements were also found in tumulus 5. A small piece of sheet copper also came to light in tumulus 26 .

In tumulus 7 there were a number of elements, not only metal ones, suggesting that this tumulus had been equipped with a wooden chest or box. The state of preservation of iron bolt $\mathrm{Z}_{7} / 6$ [Cat. 56] indicates that it was damaged due to the actions of robbers (broken ring, side lever and main shank). This tumulus also yielded a set of iron fittings and nails, of non-standard dimensions and very different features from those of the bed frame fittings, among them $\mathrm{Z}_{7} / 1$ [Cat. 27], $\mathrm{Z}_{7} / 19.1$ [Cat. 32] and Z7/19.2 [Cat. 5o]. These fittings were short and thin, with no textile impressions. One of them, $\mathrm{Z}_{7} / 1$, bore an impression of several 4-mm-thick and 4-mm-deep notches made in wood for 
the corner joint of an item of furniture, probably a box. In addition to the iron fittings found in tumulus 7 , there was also a pair of badly damaged copper fittings, $\mathrm{Z}_{7} / 19.2$, featuring small nail holes of $2 \mathrm{~mm}$ in diameter. These fittings probably came from the same box. A piece of sheet copper decorated with a cross executed in repousse $\left(\mathrm{Z}_{7} / 7\right)$ is also part of this box (see Chapter 5 , Fig. 5.14, this volume). Longitudinal rods of almost $10 \mathrm{~cm}$ long connected with small copper clamps $\mathrm{Z}_{7} / 5$, and bone elements with traces of drilling and rust from nails, as well as pieces of inlays probably made of shell (Urszula Iwaszczuk, personal communication) could also have been part of this box. All of these elements were badly preserved, often broken and with bits missing, and none of them were found in their original contexts (they were recovered from the tunnel of tumulus 7). It is not possible to reconstruct the appearance of the original chest.

The same applies to the object or objects found in the tunnel of tumulus 4 . The delicately decorated fittings and nails found there (groups $\mathrm{Z}_{4} / 95$ and $\mathrm{Z}_{4} / 23$ ) were made of copper alloy and silver and decorated with various motifs executed in repoussé. Most of the preserved fragments of these fittings do not exceed $1 \mathrm{~cm}$ and are very fragile. All silver fittings from tumulus 4 were very delicate with a thickness of $0.04^{-0.05} \mathrm{~cm}$ (groups $\mathrm{Z}_{4} / 95$ and $\mathrm{Z}_{4} / 23$ ). They were also almost completely corroded, just like the copper ones, which means that they crumble under the lightest pressure. Only the hexagonal fittings with scarab motifs largely retained their original shape and dimensions (for more detail see Chapter 5 , this volume). In addition to the fittings in these groups, there were staples and nails, and even small pieces of wood with staples, which were preserved thanks to corrosion oxides. The silver nails and iron clamps that were found with these fittings are described above (see Chapter 17.1.2, this volume).

In addition to decorated fittings, a single crescentshaped fitting, $\mathrm{Z}_{4} / 19$ [Cat. 1], with a nail in it was found in the tunnel of tumulus 4 . This crescent-shaped fitting is well-preserved and measures $11.4 \mathrm{~cm}$ long, so the object from which it came was at least that size. The fitting could have been part of a box, although among the examples from other sites there is no analogy for the shape of this fitting. This artefact could belong to the same group as the $\mathrm{Z}_{4} / 23$ decorated fittings. It was examined by XRF spectrometric analysis in Poland (see Chapter 19, this volume).

\section{$2 \quad$ Discussion and Conclusions}

Numerous artefacts found at El-Zuma indicate that a bier had been present in at least some of the graves at this site.
Most often, this was evidenced by the framework of a bed for the body of the deceased. The remains of a bed were found in over half $(15)$ of the 28 excavated tombs. In ElZuma the remains of a burial bier were present in tumuli of types I and II, but they did not appear in small graves of type III [see Table 17.1]. In most cases, the remains of bed frame fittings and nails appeared in the main chamber or in the shaft, close to the damaged blocking wall. Tumulus 4 was the only one in which a bed frame fitting was found in the tunnel only. It seems that the sex of the deceased individual did not dictate whether or not they were buried on a bed.

The number of fitting and nail fragments that came from any one grave is often irrelevant because not a single example of a completely preserved object from either of these categories was found at El-Zuma [see Table 17.1]. The state of preservation of these finds often precludes their reconstruction. The same applies to smaller fittings from chests and boxes [Table 17.2]. Fittings and nails are often heavily damaged and fragmented, probably as a result of robber activity. Sometimes the only thing left of a nail or fitting is a rusty residue. For example, the 14 fragments of nails and bed frame fittings from tumulus 9 [see Table 17.1] tell us nothing about the original number of nails and fittings in the burial bed. Each bed required at least four fittings, one in each corner, sometimes eight if the corner was reinforced from the inside. There should have been at least twice as many nails, in addition to the solitary nails found without fittings.

Grave robbers may have tackled boxes in one of two ways. In the case of smaller boxes and chests, it was easiest to take them out of the grave and view their contents in a safe hideout. Where larger objects were concerned, or if there was a danger of being caught red-handed, the crates could also be examined on the spot. In this case, the container, which was of no value in itself to the looters and could even serve as evidence of the theft, was mercilessly destroyed. This is evidenced by the pieces of bent and broken fittings, such as $\mathrm{Z}_{7} / 19.2$ [Cat. 50], and nails and other broken elements that could have been parts of a lock or hinges (fragment $\mathrm{Z}_{7} / 6$ ) [Cat. 56]. It is worth highlighting that some boxes may additionally have been covered with thin sheets of precious metal and inlaid with expensive stones, like those discovered in Ballana (Emery and Kirwan 1938, 278-282, 383-384, Figs 95-98, Pl. 109). In these instances, the fittings and jewels could be prised off, leaving only the wooden and base metal elements.

Fragments of flat, copper plaques found in the El-Zuma graves clearly indicate the presence of furniture other than beds (probably chests or boxes). Additional evidence 
TABLE 17.2 Distribution of smaller fittings (copper and silver) and small nails

\begin{tabular}{|c|c|c|c|c|}
\hline $\begin{array}{l}\text { Tumulus } \\
\text { no. }\end{array}$ & $\begin{array}{l}\text { Type of } \\
\text { tumulus }\end{array}$ & Sex & $\begin{array}{l}\text { Smaller fittings and } \\
\text { nail fragments }\end{array}$ & Context \\
\hline T.1 & I & - & - & - \\
\hline T.2 & I & - & - & - \\
\hline T.3 & I & - & - & - \\
\hline T.4 & I & - & 117 & Tunnel \\
\hline $\mathrm{T} .5$ & I & $\mathrm{M}(?)$ & 2 & Tunnel \\
\hline T.6 & I & - & - & - \\
\hline T.7 & I & $\mathrm{M}(?)$ & 9 & Tunnel \\
\hline T.8 & I & $\mathrm{F}(?)$ & - & - \\
\hline T.9 & II & $\mathrm{M}(? ?)$ & - & - \\
\hline T.11 & II & $?$ & - & - \\
\hline T.12 & II & - & - & - \\
\hline T.13 & II & $\mathrm{M}(?)$ & - & - \\
\hline T.14 & II & $\mathrm{F}(?)$ & - & - \\
\hline T.15 & II & $\mathrm{F}(?)$ & - & - \\
\hline T.16 & II & $\mathrm{M}(? ?)$ & - & - \\
\hline T.23 & II & - & - & - \\
\hline T.24 & II & $\mathrm{F}(?)$ & - & - \\
\hline T.25 & II & $\mathrm{F}$ & - & - \\
\hline T.26 & II & $\mathrm{F}$ & 1 & Shaft (near damaged blocking wall) \\
\hline T.10 & III & M & - & - \\
\hline T.17 & III & $\mathrm{M}$ & - & - \\
\hline T.18 & III & $\mathrm{F}(?)$ & - & - \\
\hline T.19 & III & $\mathrm{M}(?)$ & - & - \\
\hline T.2O & III & $\mathrm{M}(? ?)$ & - & - \\
\hline T.21 & III & $\mathrm{M}$ & - & - \\
\hline T.22 & III & M & - & - \\
\hline T.27 & III & M & - & - \\
\hline T.28 & III & $\mathrm{F}$ & - & - \\
\hline Total & & & 129 & \\
\hline
\end{tabular}

PRODUCED BY Ł. ZIELIŃSKI

comes in the form of various, mostly iron, rods of circular cross-section, measuring no more than $1.5 \mathrm{~cm}$ in diameter and often significantly exceeding $5 \mathrm{~cm}$ in length. These pieces of long, narrow rods do not have the characteristics of weapon components, and may have come from the hinge of a box lid. Lids of all kinds were mounted on such hinges. Rods were also components of lock mechanisms, the best example being the iron rod from tumulus 7 , fragment $\mathrm{Z}_{7} / 6$ [Cat. 56]. Small fragments of copper plates and rods may also indicate the presence of boxes in tumuli 5 and 26.

At least two graves (tumuli 4 and 7) certainly contained a box. The construction of the one in tumulus 7 may have been comparable to that of chest Cat. No. 881 from Qustul Tomb 14-77 (Emery and Kirwan 1938, 383384 , Fig. 118, Pl. 109). Similarities include the use of ivory inlays, copper alloy fittings, and hinges and a bolt featuring iron elements. Inlaid boxes and caskets were also found in graves at Karanog (Woolley and Randall-MacIver 1910, 32-33, 44, Pls 21-22, 24) dated from the 1st to 5 th century AD. The chests from Qustul and Karanog were mostly made of wood, and probably so was the chest from tumulus 7 in El-Zuma. The wooden elements connected with copper clamps $\mathrm{Z}_{7} / 5$ [Cat. 54] found in tumulus 7 suggest this kind of technology may have been used to build the chest. Casket 7517 found in grave 445 at Karanog (Woolley and Randall-MacIver 1910, Pl. 22) was reinforced with bronze fittings on the lower corners. The same reinforce- 
ment technique could have been used in the chest from tumulus 7 at El-Zuma (with fitting sets $Z_{7} / 19.2$ and $Z_{7} / 1$ ).

The box or boxes from tumulus 4 may have been of similar construction to that of the Gemmai box (see Chapter 7 , this volume; Scholz 2009) and casket Cat. No. 427 from grave B4-9 in Ballana (Emery and Kirwan 1938, 280, Fig. 98). These kinds of wooden boxes were completely covered with decorative metal fittings, but no inlays. The fittings recovered from tumulus 4 in El-Zuma were made of silver and copper. The box from Gemmai was embellished with silver fittings, while casket 427 from Ballana was clad with bronze fittings. However, the particulars of their construction were not discussed in detail by the excavators. In the case of casket 427, Emery (Emery and Kirwan 1938, 280, Fig. 98) describes the fittings as having been soldered together, but there was no evidence of soldering on the fittings recovered from tumulus 4 in El-Zuma, though this may be attributable to their poor state of preservation.

Compared to other sites of the period, El-Zuma falls somewhere between El-Hobagi and Qustul and Ballana. Beds and boxes were found at the royal cemeteries of Ballana and Qustul as well as in El-Zuma (see Discussion above). The difference is that the royal objects were much grander (they were made using many precious materials and were richly decorated) in comparison to those from El-Zuma. Another key difference is that the objects from Ballana and Qustul survived in good condition. In El-Zuma mostly only metal fragments survived. Beds were also found at El-Hobagi (Lenoble 2018, 195-197), but no boxes were mentioned. At smaller cemeteries like Shemkhiya 5 or Shemkhiya 10 in the Fourth Nile Cataract region (Żurawski 2008, 433-436, 441), the deceased were buried without a bed or boxes. In some cases the body was placed on a mat, so a bed was unnecessary (Żurawski 2008, 433436). At the El-Detti cemetery, which is close to El-Zuma, a padlock was found in tumulus 4 (Zieliński 2016), but there were no bed fragments in any of the excavated graves.

The grave assemblages from El-Zuma demonstrate that Nubian culture was still rooted in Egyptian influences and traditions. Placing the body on a bed for burial (see Volume I, Chapter 3; Volume II, Chapter 2) harks back to C-Group traditions in Lower Nubia, where the first evidence of bed burials appears towards the end of the CGroup period. Egyptian rule and cultural influences led to increased numbers and varieties of grave goods and equipment. Nubian pottery and Egyptian imports as well as jewellery, beds, and chests became prominent among the items with which the dead were provided for the afterlife. Differences in wealth are also very clearly evident in the burial assemblages at El-Zuma. Chests were gener- ally found in the largest tumuli, whilst bed fittings were mainly recovered from tumuli of types I and II. The smallest tumuli (type III) were the most sparsely furnished, even in terms of their pottery assemblages. Bodies were probably buried without a bed in these tombs. Other postMeroitic sites, such as Shemkhiya 5, show that the vast majority of the population were buried with neither beds nor chests, as evidenced by the more modest type II tumuli at El-Zuma.

\section{Catalogue}

\section{Cat. 1}

Crescent-shaped fitting

Inv. no.: $\mathrm{Z}_{4} / 19$

Context data: Tumulus 4, layer 4

Dimensions: $\mathrm{L}=11.4 \mathrm{~cm}, \max \mathrm{W}=3.5 \mathrm{~cm}, \mathrm{Th}=0.07 \mathrm{~cm}$; nail $\mathrm{D}=0.1 \mathrm{~cm}$

Material: Copper

Description: Crescent-shaped copper fitting with one extant copper nail and some small nail holes.

\section{Cat. 2}

Nail

Inv. no.: $\mathrm{Z1} / 35$

Context data: Tumulus 1, chamber 1, central part

Dimensions: $\mathrm{L}=6.2 \mathrm{~cm}$ (reconstructed), cross-section $=0.47 \mathrm{~cm} \times 0.56 \mathrm{~cm}$, head $=1.43 \mathrm{~cm} \times 1 \mathrm{~cm}$

Material: Iron

Description: Heavily corroded and bent nail.

Cat. 3

Nail

Inv. no.: $\mathbf{Z 1} / \mathbf{3 6}$

Context data: Tumulus 1, chamber 1, central part

Dimensions: $\mathrm{L}=4.88 \mathrm{~cm}$, cross-section $=1.05 \mathrm{~cm} \times 0.95 \mathrm{~cm}$ Material: Iron

Description: Heavily corroded nail.

Notes: One nail selected from group of nail and fitting fragments.

Cat. 4

Nail

Inv. no.: $\mathbf{Z 1} / \mathbf{3 8}$

Context data: Tumulus 1, chamber 1, central part

Dimensions: $\mathrm{L}=3.14 \mathrm{~cm}$, cross-section $=0.8 \mathrm{~cm} \times 0.84 \mathrm{~cm}$, head $=1.99 \mathrm{~cm}$

Material: Iron

Description: Heavily corroded nail. 


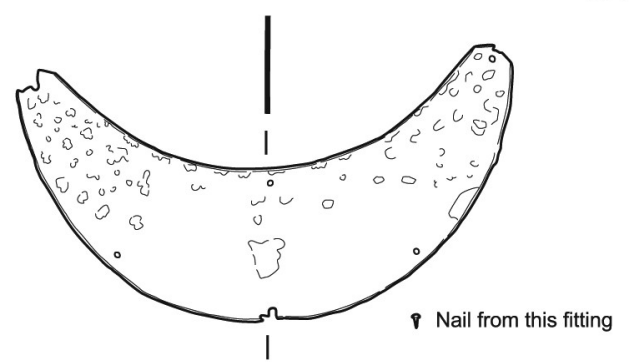

Cat. 1

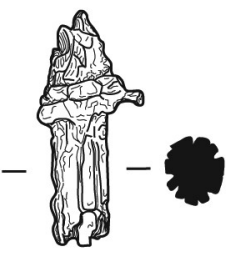

Cat. $5 \quad Z 4 / 7.2$

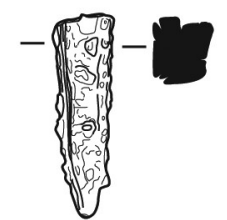

Cat. $6 \quad Z 4 / 16$

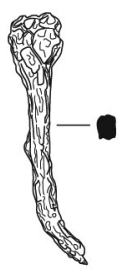

Cat. $2 Z 1 / 35$

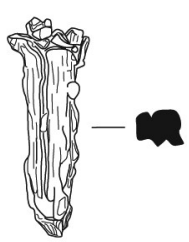

Cat. 3 Z1/36

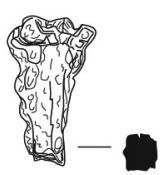

Cat. 4 Z1/38

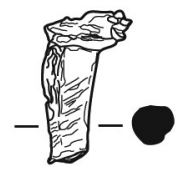

Cat. $9 \quad Z 5 / 15$

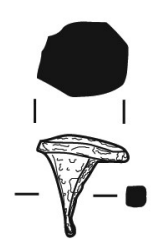

Cat. $7 \quad Z 4 / 22$

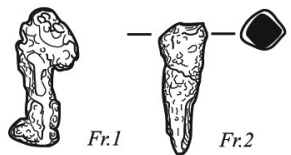

Cat. $11 \quad Z 8 / 9$
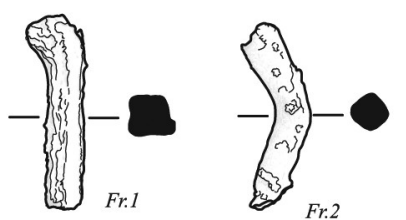

Cat. 13

$Z 9 / 20$

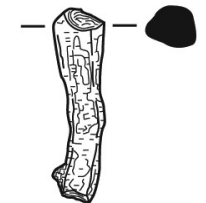

Cat. $10 Z 8 / 8$

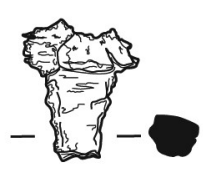

Cat. $8 \quad Z 5 / 11$

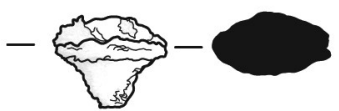

Cat. 12

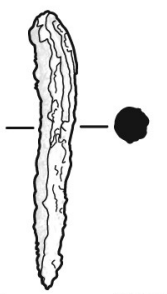

Z9/18

0 $5 \mathrm{~cm}$

FIGURE 17.1 Crescent-shaped fitting and nails

$\mathrm{z} 4 / 19, \mathrm{z} 1 / 35, \mathrm{z} 1 / 36, \mathrm{z} 1 / 38, \mathrm{z} 4 / 7.2, \mathrm{z} 4 / 16, \mathrm{z} 4 / 22, \mathrm{z} 5 / 15, \mathrm{z} 8 / 8, \mathrm{z} 8 / 9$ DRAWN AND

DIGITISED BY Ł. ZIELIŃSKI; Z5/11 DRAWN BY A. BŁASZCZYK, DIGITISED BY Ł. ZIELIŃ-

SKI; Z9/18, z9/2O DRAWN BY K. JUSZCZYK, DIGITISED BY U. IWASZCZUK

Cat. 5

Nail fragment

Inv. no.: $\mathbf{Z} 4 / 7.2$

Context data: Tumulus 4 , tunnel

Dimensions: $\mathrm{L}=5.5 \mathrm{~cm}$, rounded cross-section $=1.5 \mathrm{~cm}$

Material: Iron

Description: Heavily corroded nail (shank fragment).

Cat. 6

Nail

Inv. no.: $\mathrm{Z}_{4} / \mathbf{1 6}$
Context data: Tumulus 4, layer 5

Dimensions: $\mathrm{L}=4.8 \mathrm{~cm}$, square cross-section $=1.4 \mathrm{~cm} \times$ $1.5 \mathrm{~cm}$

Material: Iron

Description: Heavily corroded and broken nail fragments. Notes: One nail selected from group of nail and fitting fragments.

Cat. 7

Nail

Inv. no.: $\mathrm{Z}_{4} / \mathbf{2 2}$ 
Context data: Tumulus 4, layer 5

Dimensions: $\mathrm{L}=2.4 \mathrm{~cm}$; square cross-section $=1.1 \mathrm{~cm} \times$ $1.1 \mathrm{~cm}$

Material: Iron

Description: Heavily corroded fragment.

Notes: One nail selected from group of nine nail fragments and one mandrel fragment.

\section{Cat. 8}

Nail

Inv. no.: $\mathrm{Z}_{5} / \mathbf{1 1}$

Context data: Tumulus 5, chamber 1, E part

Dimensions: $\mathrm{L}=3.2 \mathrm{~cm}$, head $=2.6 \mathrm{~cm}$, cross-section $=1.2 \mathrm{~cm} \times 1.2 \mathrm{~cm}$

Material: Iron

Description: Heavily corroded and broken nail fragment.

Notes: One nail selected from group of two nail fragments.

Cat. 9

Nail fragment

Inv. no.: $\mathrm{Z}_{5} / \mathbf{1 5}$

Context data: Tumulus 5 , tunnel fill

Dimensions: $\mathrm{L}=3.5 \mathrm{~cm}$, cross-section $=0.8-0.9 \mathrm{~cm}$

Material: Iron

Description: Heavily corroded and broken nail fragment.

Cat. 10

Nail fragment

Inv. no.: $\mathrm{Z8} / 8$

Context data: Tumulus 8, burial chamber, E part

Dimensions: $\mathrm{L}=4.4 \mathrm{~cm}$, square cross-section $=0.9 \mathrm{~cm} \times$ $0.9 \mathrm{~cm}$

Material: Iron

Description: Heavily corroded and broken nail.

Cat. 11

Two nail fragments

Inv. no.: $\mathrm{Z8} / 9$

Context data: Tumulus 8, robber hole (bottom of shaft)

Dimensions: Fr. 1: $\mathrm{L}=3.2 \mathrm{~cm}$, square cross-section $=0.8 \mathrm{~cm}$ $\times 0.8 \mathrm{~cm}$

Fr. 2: $\mathrm{L}=3 \mathrm{~cm}$, square cross-section $=0.7 \mathrm{~cm} \times 0.7 \mathrm{~cm}$

Material: Iron

Description: Heavily corroded and broken nails.

Cat. 12

Head and shank of nail, from group of four nail fragments

Inv. no.: $\mathrm{Z9} / \mathbf{1 8}$

Context data: Tumulus 9, chamber 1, central part
Dimensions: Fr. 1: $\mathrm{L}=2.1 \mathrm{~cm}$, head $=1.4 \mathrm{~cm} \times 2.6 \mathrm{~cm}$

Fr. 2: $\mathrm{L}=6.2 \mathrm{~cm}$; square cross-section $=0.7 \mathrm{~cm} \times 0.7 \mathrm{~cm}$

Material: Iron

Description: Heavily corroded and broken nail fragments.

Cat. 13

Two nail fragments

Inv. no.: $\mathrm{Z} \mathbf{9} / \mathbf{2}$ o

Context data: Tumulus 9, chamber 1, E part, near the human bones

Dimensions: Fr. 1: $\mathrm{L}=5.2 \mathrm{~cm}$, rectangular cross-section $=10.4 \mathrm{~cm} \times 9.2 \mathrm{~cm}$

Fr. 2: $\mathrm{L}=4.3 \mathrm{~cm}$, square cross-section $=0.6 \mathrm{~cm} \times 0.6 \mathrm{~cm}$

Material: Iron

Description: Heavily corroded and broken nail fragment.

Cat. 14

Two nails from group of 10 nail fragments

Inv. no.: $\mathrm{Z13} / 4$

Context data: Tumulus 13, shaft, SE part, near damaged blocking wall

Dimensions: Fr. $1: \mathrm{L}=2.5 \mathrm{~cm}$, square cross-sections from $1.1 \mathrm{~cm} \times 1.1 \mathrm{~cm}$

Fr. 2: $\mathrm{L}=3.5 \mathrm{~cm}$, square cross-section $=0.9 \mathrm{~cm} \times 0.9 \mathrm{~cm}$

Material: Iron

Description: Heavily corroded and broken nails.

Cat. 15

Three nail fragments

Inv. nos.: $\mathrm{Z14} / 31.4, \mathrm{Z14} / 31.3, \mathrm{Z14} / 31.6$

Context data: Tumulus 14, chamber 1, E part

Dimensions: $\mathrm{Z} 14 / 31.4: \mathrm{L}=5.3 \mathrm{~cm}$, head $=1.7 \mathrm{~cm}$, square cross-section $=0.8 \mathrm{~cm} \times 0.8 \mathrm{~cm}$

Z14/31.3: $\mathrm{L}=6.4 \mathrm{~cm}$, square cross-section $=1.1 \mathrm{~cm} \times 1 \mathrm{~cm}$

$\mathrm{Z} 14 / 31.6: \mathrm{L}=4.6 \mathrm{~cm}$, rectangular cross-section $=0.8 \mathrm{~cm} \times$ $1 \mathrm{~cm}$

Material: Iron

Description: Heavily corroded and broken nails.

Notes: Three nail fragments selected from group of 10 nail fragments.

Cat. 16

Two nail fragments

Inv. no.: $\mathrm{Z14} / \mathbf{3 2}^{2}$

Context data: Tumulus 14, chamber 1, next to $\mathrm{W}$ wall

Dimensions: Fr. $1: \mathrm{L}=5.8 \mathrm{~cm}$, rectangular cross-section $=0.9 \mathrm{~cm} \times 0.75 \mathrm{~cm}$

Fr. 2: $\mathrm{L}=3.2 \mathrm{~cm}$, rectangular cross-section $=0.8 \mathrm{~cm} \times 0.6 \mathrm{~cm}$ Material: Iron

Description: Two heavily corroded and broken nails. 


\section{Cat. 17}

Three nail fragments

Inv. no.: $\mathrm{Z15} / 55$

Context data: Tumulus 15, main burial chamber, E part

Dimensions: Fr. $2: \mathrm{L}=4.5 \mathrm{~cm}$, square cross-section $=0.8 \mathrm{~cm}$ $\times 0.8 \mathrm{~cm}$

Fr. 3: $\mathrm{L}=3.7 \mathrm{~cm}$, oval cross-section $=0.6 \mathrm{~cm} \times 1 \mathrm{~cm}$

Fr. 4: $\mathrm{L}=3.7 \mathrm{~cm}$, rectangular cross-section $=0.8 \mathrm{~cm} \times 1 \mathrm{~cm}$

Material: Iron

Description: Heavily corroded and broken nails

Notes: Three nail fragments selected from a group of 14 fragments.

Cat. 18

Nail with sheet metal from anghareb fitting (selected from $\mathrm{Z}_{15} / 55$ )

Inv. no.: Z15/55.1

Dimensions: $\mathrm{L}=6.5 \mathrm{~cm}$, rectangular cross-section $=0.7 \mathrm{~cm}$ $\times 1.3 \mathrm{~cm}$

Material: Iron

Description: Heavily corroded and broken nail.

Cat. 19

Nail with sheet metal from anghareb fitting (selected from Z15/55)

Inv. no.: $\mathrm{Z15} / 55.2$

Dimensions: $\mathrm{L}=6.7 \mathrm{~cm}$, rectangular cross-section $=0.7 \mathrm{~cm}$ $\times 1.1 \mathrm{~cm}$

Material: Iron

Description: Heavily corroded and broken nail.

Cat. 20

Four nail fragments

Inv. no.: Z24/31

Context data: Tumulus 24, chamber 1, E part (next to wall of shaft)

Dimensions: Fr. 1 with sheet metal fitting: $\mathrm{L}=4.5 \mathrm{~cm}$, rectangular cross-section $=0.8 \mathrm{~cm} \times 0.7 \mathrm{~cm}$

Fr. 2: $\mathrm{L}=6.8 \mathrm{~cm}$, head $=1.9 \mathrm{~cm} \times 0.9 \mathrm{~cm}$, rectangular crosssection $=0.7 \mathrm{~cm} \times 1.3 \mathrm{~cm}$

Fr. 3 with sheet metal fitting: $\mathrm{L}=5.7 \mathrm{~cm}$, rectangular crosssection $=0.5 \mathrm{~cm} \times 0.9 \mathrm{~cm}$

Fr. 4: $\mathrm{L}=6 \mathrm{~cm}$, head $=2 \mathrm{~cm} \times 1.5 \mathrm{~cm}$, rectangular crosssection $=0.6 \mathrm{~cm} \times 1.2 \mathrm{~cm}$

Material: Iron

Description: Heavily corroded and broken nail fragments.

Notes: Four nail fragments selected from group of 10 nail fragments.
Cat. 21

Sheet metal fitting of anghareb

Inv. no.: Z24/31.10 (selected from Z24/31)

Dimensions: $\mathrm{L}=5 \mathrm{~cm}, \mathrm{~W}=4.7 \mathrm{~cm}, \mathrm{Th}=0.4-0.5 \mathrm{~cm}$

Material: Iron

Description: Heavily corroded sheet metal featuring textile impression.

Cat. 22

One nail fragment

Inv. no.: $\mathbf{Z 2 6 / 3}$

Context data: Tumulus 26, chamber 1 , near damaged blocking wall

Dimensions: $\mathrm{L}=3.5 \mathrm{~cm}$, square cross-section $=0.9 \mathrm{~cm} \times$ $0.9 \mathrm{~cm}$

Material: Iron

Description: Heavily corroded and broken nail fragment.

Cat. 23

Three nail fragments

Inv. no.: $\mathrm{Z26} / 7$

Context data: Tumulus 26, chamber 1, E part, near human bones

Dimensions: Fr. 1: $\mathrm{L}=5.2 \mathrm{~cm}$, square cross-section $=0.8 \mathrm{~cm}$ $\times 0.8 \mathrm{~cm}$

Fr. 2: $\mathrm{L}=4.4 \mathrm{~cm}$, square cross-section $=0.7 \mathrm{~cm} \times 0.8 \mathrm{~cm}$

Fr. $3: \mathrm{L}=4 \mathrm{~cm}$, circular cross-section $=0.7 \mathrm{~cm} \times 0.8 \mathrm{~cm}$

Material: Iron

Description: Heavily corroded and broken nail fragments.

Cat. 24

One fragment of fitting

Inv. no.: $\mathrm{Z}_{4} / 143$

Context data: Tumulus 4, W tunnel, entrance to burial chamber

Dimensions: $\mathrm{L}=7 \mathrm{~cm}, \mathrm{~W}=3.3 \mathrm{~cm}, \mathrm{Th}=0.4 \mathrm{~cm}$

Material: Iron

Description: Heavily corroded fitting fragment.

Notes: One fragment of fitting selected from group of 16 nails and fitting fragments.

Cat. 25

Fitting

Inv. no.: $\mathrm{Z}_{\mathbf{4} / \mathbf{1 8 9}}$

Context data: Tumulus 4, E tunnel, N part

Dimensions: $\mathrm{L}=3.5 \mathrm{~cm}, \mathrm{~W}=1.1 \mathrm{~cm}, \mathrm{Th}=0.4 \mathrm{~cm}$

Material: Iron

Description: Heavily corroded fitting.

Notes: One fitting selected from group of seven nails and eight fitting fragments. 
BURIAL EQUIPMENT
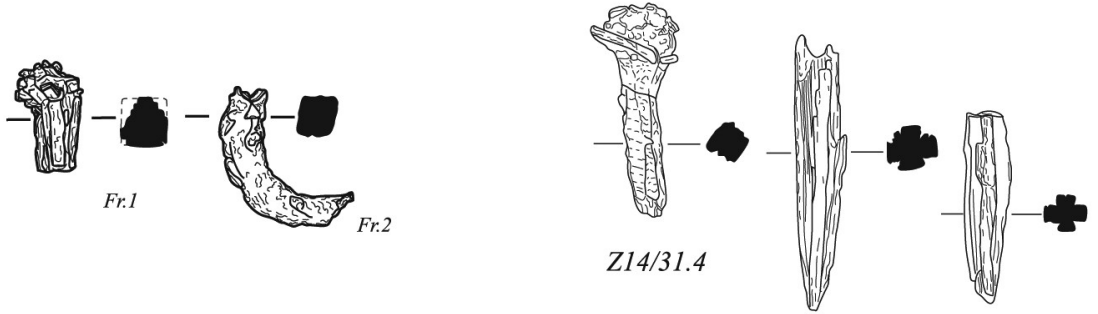

Cat. 14

$Z 13 / 4$

Cat. 15

Z14/31.3

Z14/31.6

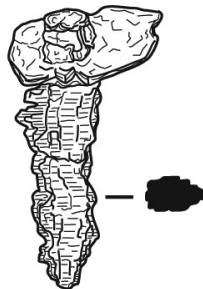

Cat. $18 \quad Z 15 / 55.1$

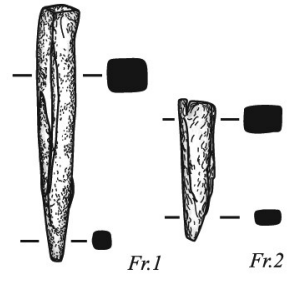

Cat. 16

Z14/32

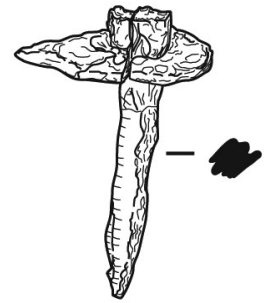

Cat. $19 \quad Z 15 / 55.2$

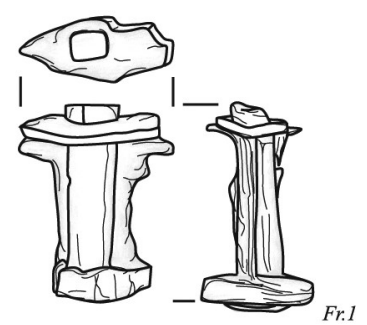

Cat. 20

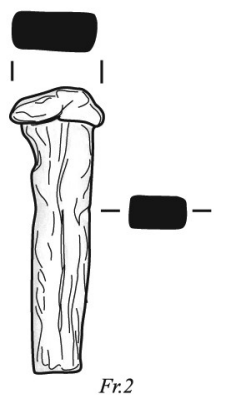

Fr.2

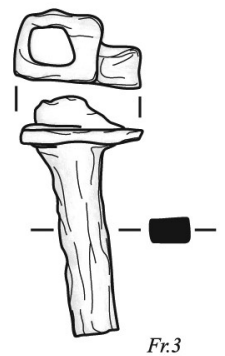

Fr. 3

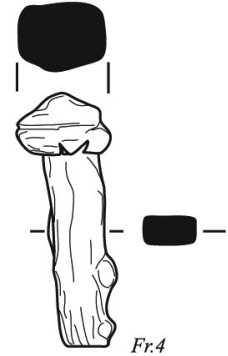

Z24/31

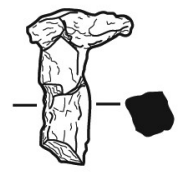

Cat. $22 \quad Z 26 / 3$ $5 \mathrm{~cm}$

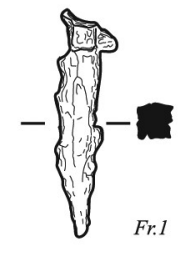

Cat. 23
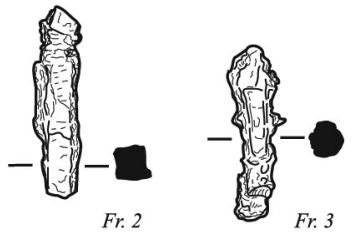

Z26/7

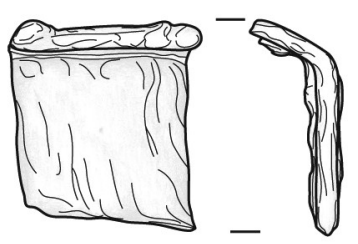

Cat. 21

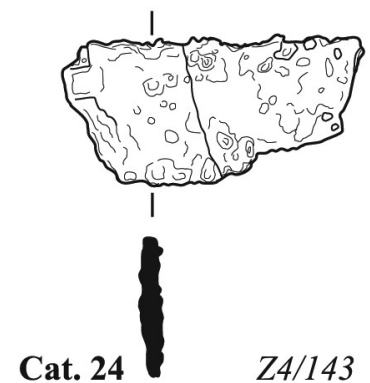

Cat. 24

Z4/143

FIGURE 17.2 Nails and fitting elements

$\mathrm{Z13} / 4, \mathrm{z} 15 / 55, \mathrm{z} 15 / 55.1, \mathrm{z} 15 / 55.2, \mathrm{z} 26 / 3, \mathrm{z} 26 / 7, \mathrm{z} 4 / 143$ DRAWN AND DIGITISED BY Ł. ZIELIŃSKI; Z14/31.4, Z14/31.3, Z14/31.6, Z14/32, Z24/31, Z24/31.10 DRAWN BY R. HAJDUGA, DigITISED BY E. CZYŻEWSKA-ZALEWSKA 
Cat. 26

Nail

Inv. no.: $\mathrm{Z}_{5} / \mathbf{1 2}$

Context data: Tumulus 5, chamber 1, part E

Dimensions: $\mathrm{L}=4.8 \mathrm{~cm}$, sub-circular cross-section $=0.9-$ $1 \mathrm{~cm}$

Material: Iron

Description: Heavily corroded and broken fragment.

Notes: One nail selected from group of two fragments: a nail and an n-shaped plate fragment (fitting).

Cat. 27

Fitting fragment

Inv. no.: $\mathrm{Z}_{7} / \mathbf{1}$

Context data: Tumulus 7 , layer 5

Dimensions: $\mathrm{L}=3.6 \mathrm{~cm}, \mathrm{~W}=3 \mathrm{~cm}, \mathrm{Th}=0.3 \mathrm{~cm}$

Material: Iron

Description: Heavily corroded and broken fitting.

Notes: One fitting fragment selected from group of three nail fragments and two fitting fragments.

Cat. 28

Three nails

Inv. no.: Z24/9

Context data: Tumulus 24, chamber 2, W part

Dimensions: Fr. 1, nail with sheet metal fitting: $\mathrm{L}=4.8 \mathrm{~cm}$, rectangular cross-section $=0.6 \mathrm{~cm} \times 0.6 \mathrm{~cm}$; sheet metal fitting $\mathrm{Th}=0.2 \mathrm{~cm}$

Fr. 2, nail: $\mathrm{L}=4.2 \mathrm{~cm}$, rectangular cross-section $=0.9 \mathrm{~cm} \times$ $1 \mathrm{~cm}$

Fr. 3, bent nail: $\mathrm{L}=6.1 \mathrm{~cm}$, circular cross-section $=0.9 \mathrm{~cm} \times$ $0.9 \mathrm{~cm}$

Material: Iron

Description: Heavily corroded and broken nails.

Notes: Three nails selected from group of seven nail fragments with sheet metal fitting.

\section{Cat. 29}

Seven fragments of nails and bed frame fittings

Inv. no.: $\mathbf{Z 2 4 / 1 6}$

Context data: Tumulus 24, chamber 1, near blocking wall, NE corner

Dimensions: Fr. 1, nail: $\mathrm{L}=3.7 \mathrm{~cm}$, square cross-section $=1 \mathrm{~cm} \times 1.1 \mathrm{~cm}$

Fr. 2, nail: $\mathrm{L}=1.7 \mathrm{~cm}$, square cross-section $=1 \mathrm{~cm} \times 1 \mathrm{~cm}$

Fr. 3 , nail: $\mathrm{L}=3 \mathrm{~cm}$, oval cross-section $=0.7 \mathrm{~cm} \times 1 \mathrm{~cm}$

Fr. 4, fitting: $\mathrm{L}=5.5 \mathrm{~cm}, \mathrm{~W}=3.2 \mathrm{~cm}, \mathrm{Th}=0.6 \mathrm{~cm} \times 0.7 \mathrm{~cm}$

Fr. 5, fitting: $\mathrm{L}=3 \mathrm{~cm}, \mathrm{~W}=2 \mathrm{~cm}, \mathrm{Th}=0.5 \mathrm{~cm}$

Fr. 6, fitting: $\mathrm{L}=2.5 \mathrm{~cm}, \mathrm{~W}=1.5 \mathrm{~cm}, \mathrm{Th}=0.3 \mathrm{~cm}$

Fr. 7, fitting: $\mathrm{L}=3 \mathrm{~cm}, \mathrm{~W}=5.2 \mathrm{~cm}, \mathrm{Th}=0.5 \mathrm{~cm} \times 0.7 \mathrm{~cm}$

Material: Iron
Description: Heavily corroded and broken nails and bed frame fittings (from same item of furniture as Z24/ $52)$.

\section{Cat. 30}

Six nails

Inv. no.: $\mathrm{Z24} / 5^{2}$

Context data: Tumulus 24, chamber 1, part E

Dimensions: Fr. 1, nail: $\mathrm{L}=7.7 \mathrm{~cm}$, head $=2.5 \mathrm{~cm} \times 1.5 \mathrm{~cm}$, rectangular cross-section $=0.8 \mathrm{~cm} \times 1.3 \mathrm{~cm}$

Fr. 2, nail: $\mathrm{L}=6.5 \mathrm{~cm}$, head $=1.6 \mathrm{~cm} \times 1 \mathrm{~cm}$, rectangular crosssection $=0.7 \mathrm{~cm} \times 1.1 \mathrm{~cm}$

Fr. 3, nail: $\mathrm{L}=9 \mathrm{~cm}$, rectangular cross-section $=0.7 \mathrm{~cm} \times$ $1.3 \mathrm{~cm}$

Fr. 4, nail: $\mathrm{L}=3.6 \mathrm{~cm}$, head $=2.36 \mathrm{~cm} \times 1 \mathrm{~cm}$, rectangular cross-section $=0.6 \mathrm{~cm} \times 1 \mathrm{~cm}$

Fr. 5, nail: $\mathrm{L}=5.5 \mathrm{~cm}$, rectangular cross-section $=0.6 \mathrm{~cm} \times$ $1.2 \mathrm{~cm}$

Fr. 6, nail with sheet metal fitting: $\mathrm{L}=4 \mathrm{~cm}$, rectangular cross-section $=0.5 \mathrm{~cm} \times 1 \mathrm{~cm}$; sheet metal fitting $\mathrm{Th}=0.5 \mathrm{~cm}$

Description: Heavily corroded and broken nails and bed frame fitting (from same item of furniture as Z24/54).

Notes: Six nails selected from group of 10 nails and bed frame fittings.

Cat. 31

One nail and one bed frame fitting fragment

Inv. no.: $\mathbf{Z 2 5 / 3 3}$

Context data: Tumulus 25, chamber 1, E part, on blocking bricks

Dimensions: Fr. 1, sheet metal fitting with nail fragment: $\mathrm{L}=3.2 \mathrm{~cm}$, rectangular cross-section $=0.3 \mathrm{~cm} \times 0.4 \mathrm{~cm}$, $\mathrm{Th}=0.3 \mathrm{~cm}$

Fr. 2 , nail: $\mathrm{L}=2.7 \mathrm{~cm}$, square cross-section $=0.9 \mathrm{~cm} \times 0.9 \mathrm{~cm}$ Material: Iron

Description: Heavily corroded and broken nail and bed frame fitting.

Cat. $3^{2}$

Two fitting fragments

Inv. no.: $\mathrm{Z}_{7} / \mathbf{1 9 . 1}$

Context data: Tumulus 7 , layer 5

Dimensions: Fr. 1, fitting: $\mathrm{L}=9.8 \mathrm{~cm}, \mathrm{~W}=1.2 \mathrm{~cm}, \mathrm{Th}=0.3 \mathrm{~cm}$

Fr. 2, fitting: $\mathrm{L}=5.7 \mathrm{~cm}, \mathrm{~W}=1.3 \mathrm{~cm}, \mathrm{Th}=0.3 \mathrm{~cm}$

Material: Iron

Description: Two fitting fragments (from a chest).

Cat. 33

Nail fragment

Inv. no.: Z9/11 


\section{BURIAL EQUIPMENT}

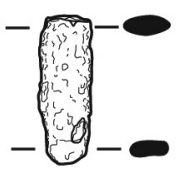

Cat. $25 \quad Z 4 / 189$

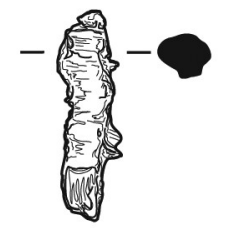

Cat. 26 Z5/12

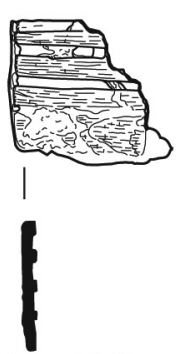

Cat. 27
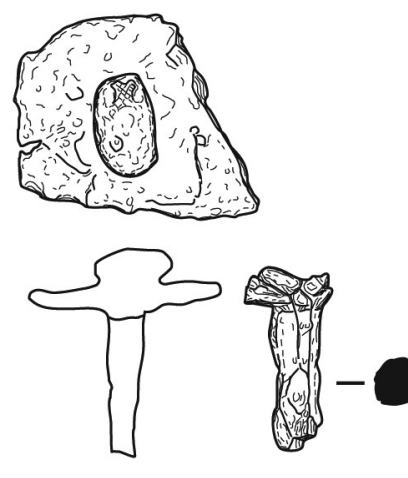

Cat. 28
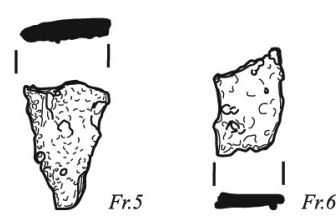

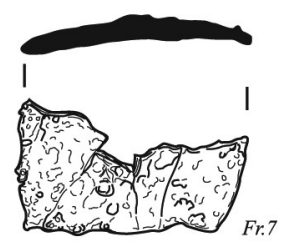

$Z 24 / 9$

Cat. 29

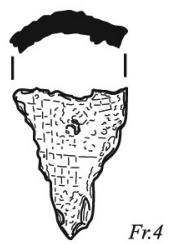

$Z 24 / 16$

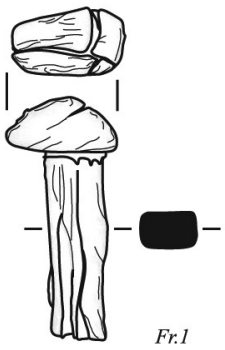

Cat. 30

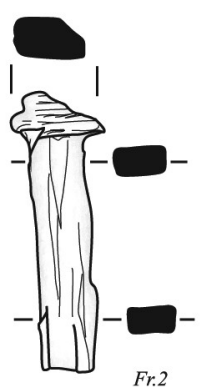

Fr.2

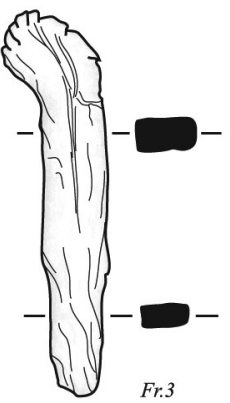

Fr.3
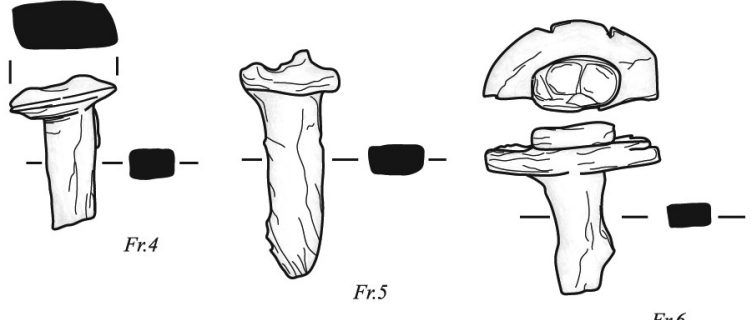

$Z 24 / 52$

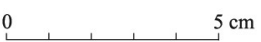

FIGURE 17.3 Nails and fitting elements

Z4/189, Z7/1, Z24/9, Z24/16 DRAWN AND DIGITISED BY Ł. ZIELIŃSKI; Z5/12 DRAWN BY A. BŁASZCZYK, DIGITISED BY Ł. ZIELIŃSKI; Z24/52 DRAWN BY R. HAJDUGA, DIGITISED BY E. CZYŻEWSKA-ZALEWSKA

Context data: Tumulus 9, shaft, S part, near damaged blocking wall of chamber 1

Dimensions: $\mathrm{L}=5 \mathrm{~cm}$, square cross-section $=0.4 \mathrm{~cm} \times$ $0.4 \mathrm{~cm}$

Material: Iron

Description: Heavily corroded and broken nail.

Cat. 34

Fitting

Inv. no. $\mathrm{Z} 4 / 17$
Context data: Tumulus 4 , layer 5

Dimensions: $\mathrm{L}=4.2 \mathrm{~cm}, \mathrm{~W}=2.9 \mathrm{~cm}, \mathrm{Th}=0.2 \mathrm{~cm}$

Material: Iron

Description: Heavily corroded fitting fragment.

Notes: One fitting selected from group of three fitting fragments.

Cat. 35

Fitting fragment

Inv. no.: $\mathrm{Z}_{4} / 72$ 
ELEMENTS OF BURIAL EQUIPMENT

125

BURIAL EQUIPMENT

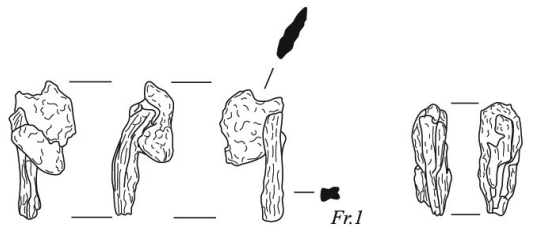

Cat. 31

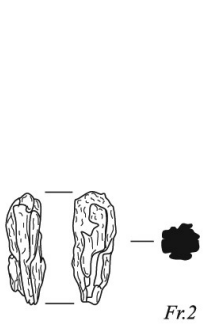

Z25/33

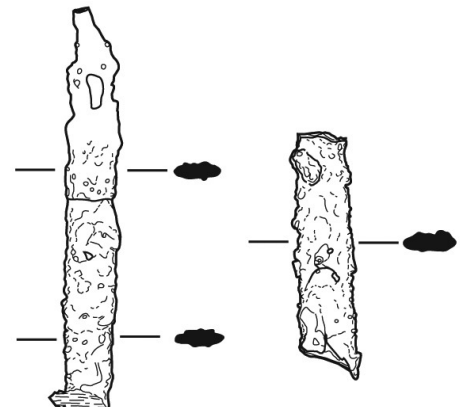

Z7/19.1

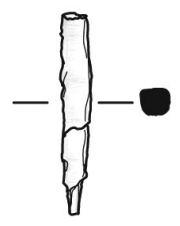

Cat. $33 \quad Z 9 / 11$

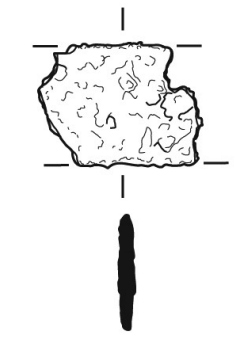

Cat. $34 \quad Z 4 / 17$
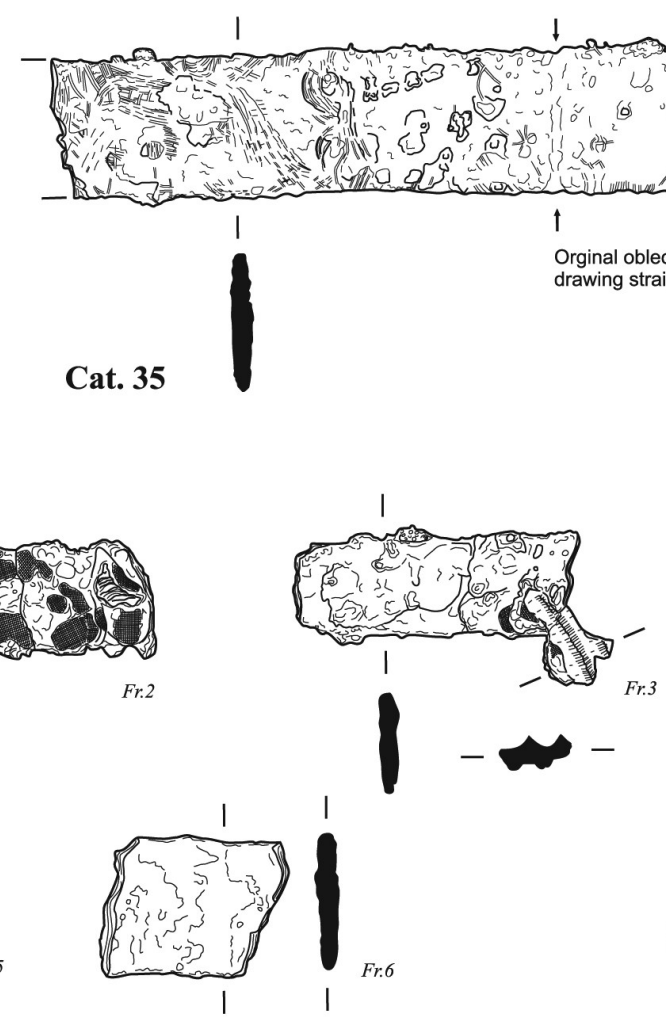

Z4/72
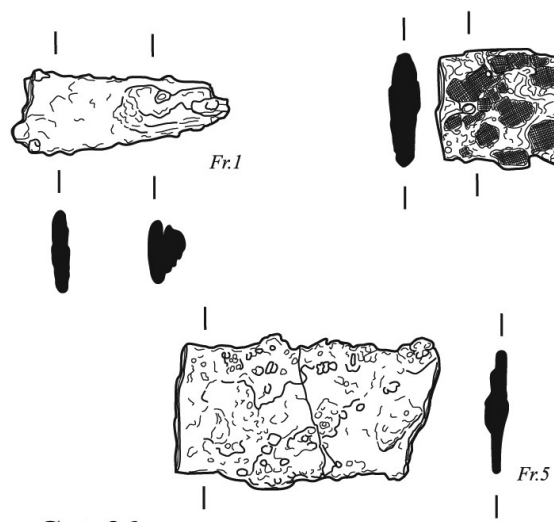

Cat. 36
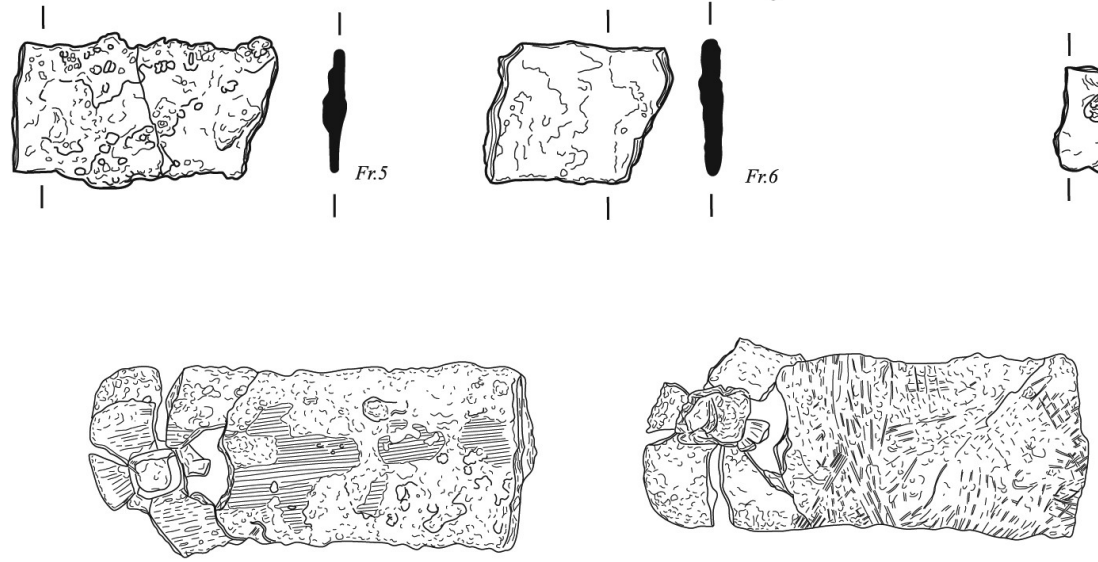

Cat. 37
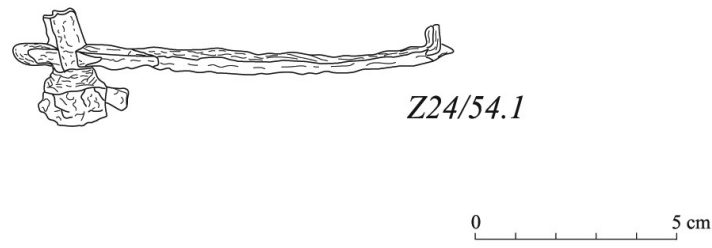

FIGURE 17.4 Fitting elements with nails Z25/33 DRAWN BY Ł. ZIELIŃSKI, DIGITISED BY E. CZYŻEWSKA-ZALEWSKA; Z7/19.1, Z4/17, Z4/72, Z4/7, Z24/54.1 DRAWN AND DIGITISED BY Ł. ZIELIŃSKI; Z9/11 DRAWN BY K. JUSZCZYK, DIGITISED BY U. IWASZCZUK

Łukasz Zieliński and Eva Czyżewska-Zalewska - 9789004433755

Downloaded from Brill.com@4/26/2023 11:48:34AM
via free access 
Context data: Tumulus 4, tunnel, E side

Dimensions: $\mathrm{L}=14.6 \mathrm{~cm}, \mathrm{~W}=3.5 \mathrm{~cm}, \mathrm{Th}=0.3 \mathrm{~cm}$

Material: Iron

Description: Fitting fragment with textile impression.

Cat. 36

Seven bed frame fitting fragments

Inv. no.: $\mathrm{Z} 4 / 7$

Context data: Tumulus 4, tunnel

Dimensions: Fr. $1: \mathrm{L}=5.2 \mathrm{~cm}, \mathrm{~W}=2.1 \mathrm{~cm}, \mathrm{Th}=0.4 \mathrm{~cm}$

Fr. 2, fitting with textile imprint: $\mathrm{L}=6.5 \mathrm{~cm}, \mathrm{~W}=2.9 \mathrm{~cm}$, $\mathrm{Th}=0.7 \mathrm{~cm}$

Fr. 3, fitting with textile imprint: $\mathrm{L}=7 \mathrm{~cm}, \mathrm{~W}=2.7 \mathrm{~cm}$, $\mathrm{Th}=0.4 \mathrm{~cm}$

Fr. 4, fitting with textile imprint: $\mathrm{L}=3.7 \mathrm{~cm}, \mathrm{~W}=3.6 \mathrm{~cm}$, $\mathrm{Th}=0.5 \mathrm{~cm}$

Fr. 5: $\mathrm{L}=6.5 \mathrm{~cm}, \mathrm{~W}=3.5 \mathrm{~cm}, \mathrm{Th}=0.5 \mathrm{~cm}$

Fr. 6: $\mathrm{L}=4.5 \mathrm{~cm}, \mathrm{~W}=3.4 \mathrm{~cm}, \mathrm{Th}=0.5 \mathrm{~cm}$

Fr. 7: $\mathrm{L}=2.8 \mathrm{~cm}, \mathrm{~W}=2.7 \mathrm{~cm}, \mathrm{Th}=0.3 \mathrm{~cm}$

Material: Iron

Description: Heavily corroded bed frame fitting fragments with traces of textiles.

Cat. 37

Fragment of bed frame fitting selected from group of six nails $Z_{24} / 54$

Inv. no.: Z24/54.1

Context data: Tumulus 24, chamber 1, E part, NE corner

Dimensions: $\mathrm{L}=10.7 \mathrm{~cm}, \mathrm{~W}=4.4 \mathrm{~cm}, \mathrm{Th}=0.5^{-0.6 \mathrm{~cm}}$

Material: Iron

Description: Heavily corroded bed frame fitting.

Cat. 38

Bed frame fitting fragment

Inv. no.: $\mathbf{Z}_{\mathbf{5}} / \mathbf{2 3}$

Context data: Tumulus 5 , tunnel fill

Dimensions: $\mathrm{L}=4.1 \mathrm{~cm}, \mathrm{~W}=1.9 \mathrm{~cm}$, Th. $=0.4 \mathrm{~cm}$

Material: Iron

Description: Heavily corroded and broken bed frame fitting fragment.

Cat. 39

Bed frame fitting fragment

Inv. no.: Z9/12

Context data: Tumulus 9, shaft, $\mathrm{S}$ part, near damaged blocking wall of chamber 1

Dimensions: $\mathrm{L}=6.1 \mathrm{~cm}, \mathrm{~W}=2.8 \mathrm{~cm}, \mathrm{Th}=0.4 \mathrm{~cm}$

Material: Iron

Description: Heavily corroded and broken bed frame fitting (with wood and textile impressions).
Cat. 40

Nail with sheet metal fitting

Inv. no.: Z9/19

Context data: Tumulus 9, chamber 1, central part

Dimensions: $\mathrm{L}=5 \mathrm{~cm}$, head $=2.1 \mathrm{~cm}$, square cross-section $=$ $0.7 \mathrm{~cm} \times 0.7 \mathrm{~cm}$; sheet metal $\mathrm{Th}=0.5 \mathrm{~cm}$

Material: Iron

Description: Heavily corroded and broken bed frame fitting with preserved nail (featuring wood and textile impressions).

Cat. 41

Three fitting fragments from a bed frame

Inv. no.: Z11/33

Context data: Tumulus 11, chamber 1, near human bones

Dimensions: Fr. 1: $\mathrm{L}=10.2 \mathrm{~cm}, \mathrm{~W}=3 \mathrm{~cm}, \mathrm{Th}=0.2 \mathrm{~cm}$

Fr. 2: $\mathrm{L}=4.6 \mathrm{~cm}, \mathrm{~W}=3 \mathrm{~cm}, \mathrm{Th}=0.2 \mathrm{~cm}$

Fr. $3: \mathrm{L}=3.7 \mathrm{~cm}, \mathrm{~W}=2.4 \mathrm{~cm}, \mathrm{Th}=0.2 \mathrm{~cm}$

Material: Iron

Description: Three bed frame fitting fragments, with two nail holes in fragments 1 and 2.

Cat. 42

Two fitting fragments from a group of five bed frame fittings

Inv. no.: $\mathrm{Z13} / \mathbf{1}$

Context data: Tumulus 13, shaft, SE part

Dimensions: Fr. 1: $\mathrm{L}=3.5 \mathrm{~cm}, \mathrm{~W}=2.1 \mathrm{~cm}, \mathrm{Th}=0.25 \mathrm{~cm}$

Fr. 2: $\mathrm{L}=10.3 \mathrm{~cm}, \mathrm{~W}=2.2-3 \mathrm{~cm}, \mathrm{Th}=0.6 \mathrm{~cm}$

Material: Iron

Description: Heavily corroded and broken bed frame fittings.

Cat. 43

Nail with sheet metal fitting

Inv. no.: $\mathrm{Z}_{15} / \mathbf{2 9}$

Context data: Tumulus 15, SE corner of shaft, near blocking wall of main burial chamber

Dimensions: $\mathrm{L}=6.4 \mathrm{~cm}$, square cross-section $=0.5 \mathrm{~cm} \times$ $0.5 \mathrm{~cm}$, sheet metal $\mathrm{Th}=0.5 \mathrm{~cm}$

Material: Iron

Description: Heavily corroded and broken bed frame fitting with preserved nail.

Cat. 44

One bed frame fitting fragment

Inv. no.: Z16/29+Z16/33

Context data: Tumulus 16, chamber 1, N part, near vessel no. 2

Dimensions: $\mathrm{L}=12 \mathrm{~cm}, \mathrm{~W}=3 \mathrm{~cm}, \mathrm{Th}=0.3 \mathrm{~cm}$

nail: square cross-section $=0.4 \mathrm{~cm} \times 0.4 \mathrm{~cm}$ 
BURIAL EQUIPMENT

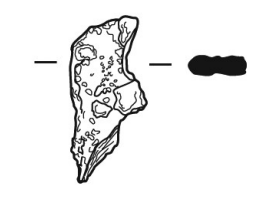

Cat. $38 \quad Z 5 / 23$

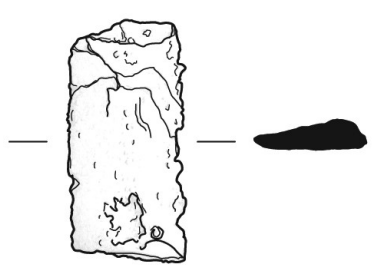

Cat. $39 \quad Z 9 / 12$

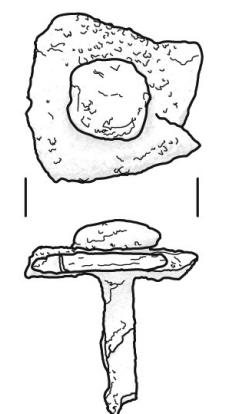

Cat. $40 \quad$ Z9/19

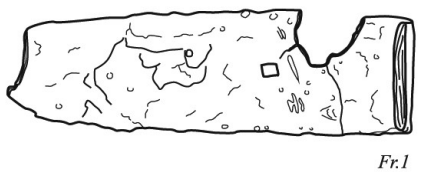

Cat. 41

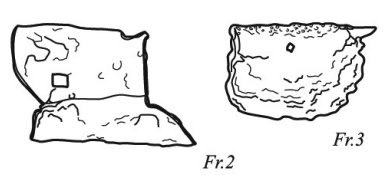

Z11/33

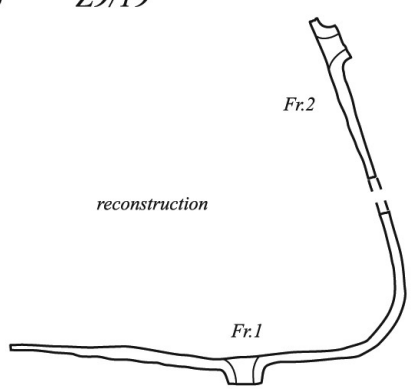

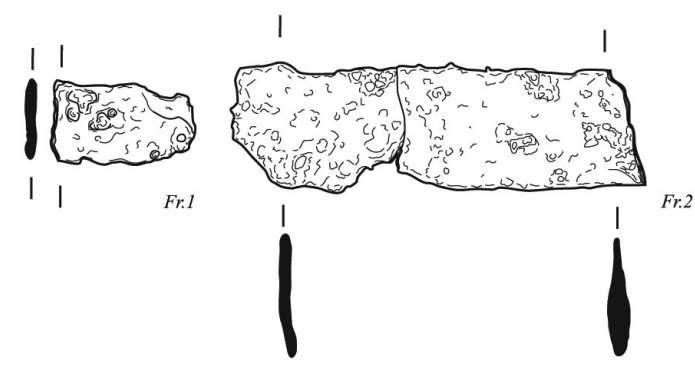

Cat. 42

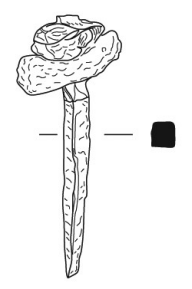

Cat. $43 \quad Z 15 / 29$

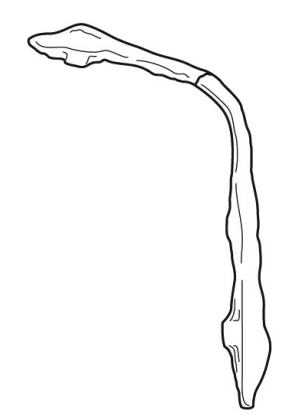

Cat. $44 \quad Z 16 / 29+Z 16 / 33$

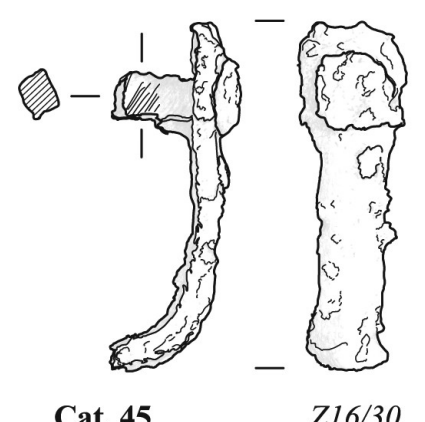

Cat. 45

$Z 16 / 30$

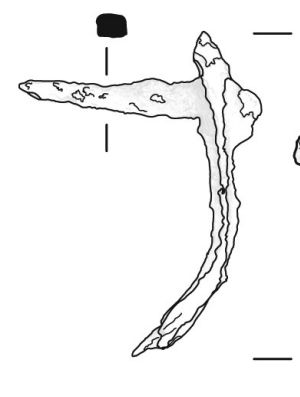

Cat. 46

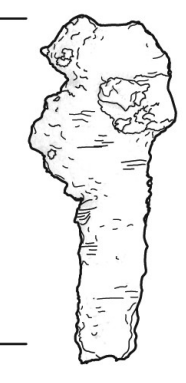

Z16/33

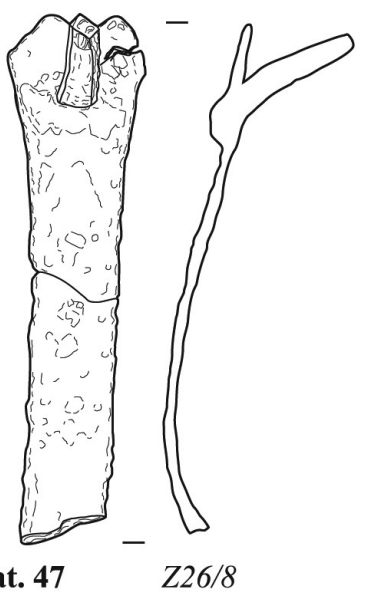

FIGURE 17.5 Fitting elements with nails

Z5/23, Z11/33, Z13/1, Z16/29+Z16/33, z/8 DRAWN AND DIGITISED BY Ł. ZIELIŃSKI;

Z9/12, z9/19, Z16/3O, z16/33 DRAWN BY K. JUSZCZYK, DIGITISED BY U. IWASZCZUK;

Z15/29 DRAWN BY Ł. ZIELIŃSKI, DIGITISED BY E. CZYŻEWSKA-ZALEWSKA 
BURIAL EQUIPMENT

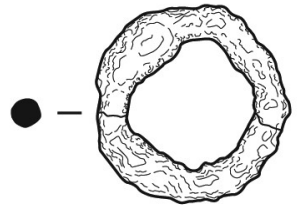

Cat. $48 \quad Z 4 / 85$

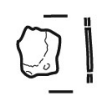

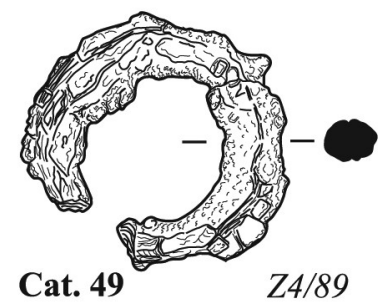

Cat. 49

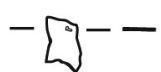

Cat. $52 \quad Z 5 / 24$

Cat. $53 \quad Z 5 / 25$

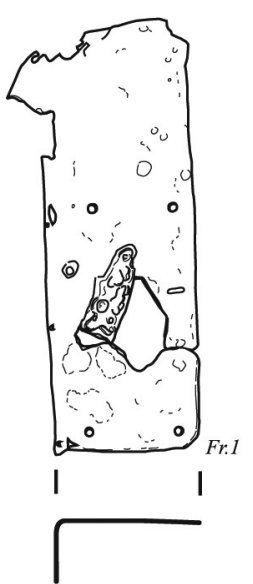

Cat. 50
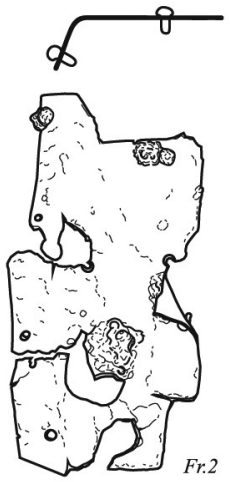

Fr.2

Z7/19.2

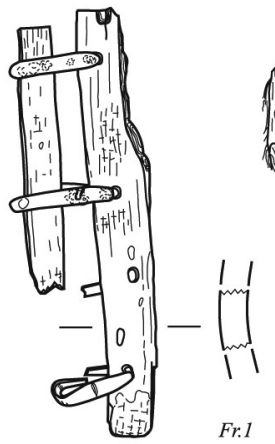

Cat. 54
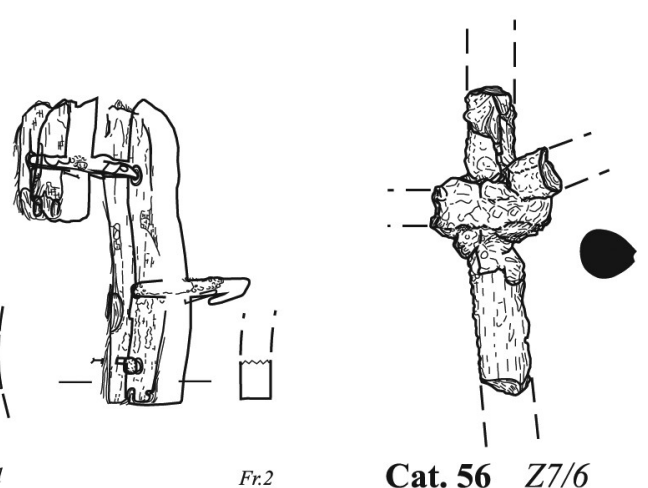

$Z 7 / 5$

Cat. $56 \quad Z 7 / 6$

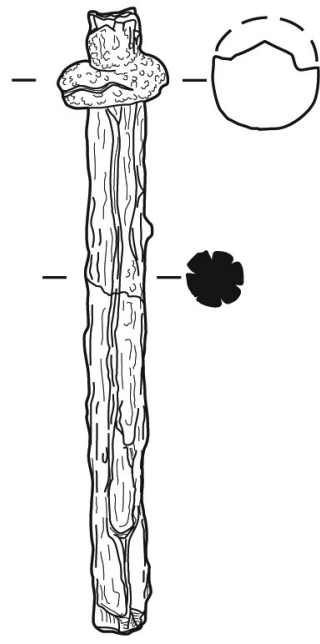

Cat. $55 Z 4 / 74$

\section{0} $5 \mathrm{~cm}$

Cat. 57
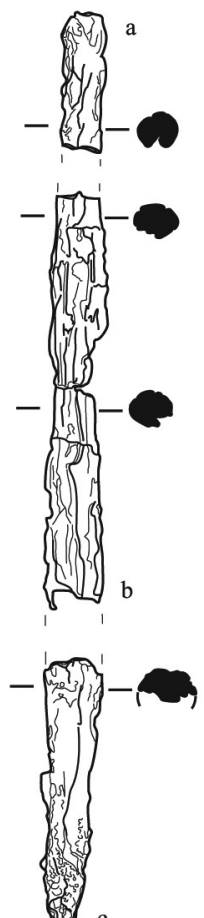

Z10/31

FIGURE 17.6 Fitting elements and rods

$\mathrm{z}_{4} / 85, \mathrm{z} 4 / 89, \mathrm{z} 7 / 19.2, \mathrm{z} 26 / 2, \mathrm{z}_{5} / 24, \mathrm{z}_{5} / 25, \mathrm{z}_{7} / 5, \mathrm{z}_{4} / 74, \mathrm{z} / 6, \mathrm{z} 1 \mathrm{O} / 31$ DRAWN AND DIGITISED BY Ł. ZIELIŃSKI 
Material: Iron

Description: One heavily corroded and broken bed frame fitting.

\section{Cat. 45}

One bed frame fitting fragment with nail fragment

Inv. no.: $\mathrm{Z16} / 3$ o

Context data: Tumulus 16, chamber 1, N part, near vessel no. 2

Dimensions: fitting: $\mathrm{L}=8.5 \mathrm{~cm}, \mathrm{~W}=2 \mathrm{~cm}, \mathrm{Th}=0.8-0.9 \mathrm{~cm}$

nail: $\mathrm{L}=3 \mathrm{~cm}$, head $=1.8 \mathrm{~cm}$, square cross-section $=0.8 \mathrm{~cm}$ $\times 1 \mathrm{~cm}$

\section{Material: Iron}

Description: One heavily corroded and broken bed frame fitting with preserved nail fragment.

\section{Cat. 46}

Bed frame fitting with nail fragment selected from group of 14 fittings

Inv. no.: $\mathrm{Z16} / 33$

Context data: Tumulus 16, chamber 1, S part, near skeleton

Dimensions: fitting: $\mathrm{L}=8 \mathrm{~cm}, \mathrm{~W}=2 \mathrm{~cm}, \mathrm{Th}=0.5 \mathrm{~cm}$

nail: $\mathrm{L}=6 \mathrm{~cm}$, rectangular cross-section $=0.7 \mathrm{~cm} \times 0.5 \mathrm{~cm}$

Material: Iron

Description: Heavily corroded and broken bed frame fitting fragment with preserved nail.

\section{Cat. 47}

One bed frame fitting fragment with nail fragment

Inv. no.: Z26/8

Context data: Tumulus 26, chamber 1, E part, near human bones

Dimensions: fitting: $\mathrm{L}=12.8 \mathrm{~cm}, \mathrm{~W}=2.3 \mathrm{~cm}, \mathrm{Th}=0.5 \mathrm{~cm}$

nail: $\mathrm{L}=4 \mathrm{~cm}$, square cross-section $=0.7 \mathrm{~cm} \times 0.7 \mathrm{~cm}$

Material: Iron

Description: Heavily corroded and broken bed frame fitting fragment.

\section{Cat. 48}

Hoop

Inv. no.: $\mathrm{Z}_{4} / 85$

Context data: Tumulus 4, W tunnel

Dimensions: Outside D $=4.5 \mathrm{~cm}$, inside D $=2.8 \mathrm{~cm}$, crosssection $=0.7 \mathrm{~cm}$

Material: Iron

Description: Heavily corroded iron hoop with preserved imprints of unknown objects.

Cat. 49

Hoop

Inv. no.: $\mathrm{Z} 4 / 89$
Context data: Tumulus 4, W tunnel

Dimensions: Outside D $=6.3 \mathrm{~cm}$, inside D $=3.5 \mathrm{~cm}$, crosssection $=1.5 \mathrm{~cm}$

Material: Iron

Description: Heavily corroded iron hoop with preserved imprints of unknown objects.

Cat. $5^{\circ}$

Two fitting fragments with pins

Inv. no.: $\mathrm{Z}_{7} / \mathbf{1 9 . 2}$

Context data: Tumulus 7 , layer 5

Dimensions: $\mathrm{Fr} .1 \mathrm{~L}=10 \mathrm{~cm}, \mathrm{~W}=3.4 \mathrm{~cm}, \mathrm{Th}=0.05 \mathrm{~cm}$

Fr. $2: \mathrm{L}=8.7 \mathrm{~cm}, \mathrm{~W}=3.2 \mathrm{~cm}, \mathrm{Th}=0.05 \mathrm{~cm}$

pin $\mathrm{D}=0.2 \mathrm{~cm}$

Material: Copper

Description: Two copper fitting fragments with pins and pin holes (from a chest).

Cat. $5^{1}$

One fitting fragment

Inv. no.: $\mathbf{Z 2 6 / 2}$

Context data: Tumulus 26, shaft, near damaged blocking wall of chamber 1

Dimensions: $\mathrm{L}=1.1 \mathrm{~cm}, \mathrm{~W}=0.9 \mathrm{~cm}, \mathrm{Th}=0.8 \mathrm{~cm}$

Material: Copper

Description: Small copper fitting fragment.

Cat. $5^{2}$

Plate fragment (fitting)

Inv. no.: $\mathrm{Z}_{5} / \mathbf{2 4}$

Context data: Tumulus 5 , tunnel fill

Dimensions: $\mathrm{L}=1.2 \mathrm{~cm}, \mathrm{~W}=0.8 \mathrm{~cm}, \mathrm{Th}=0.07 \mathrm{~cm}$

Material: Copper

Description: Copper plate fragment (fitting), probably from the same object as $\mathrm{Z}_{5} / 25$.

Cat. 53

Plate fragment (fitting)

Inv. no.: $\mathrm{Z}_{5} / \mathbf{2 5}$

Context data: Tumulus 5 , tunnel fill

Dimensions: $\mathrm{L}=1.1 \mathrm{~cm}, \mathrm{~W}=0.8 \mathrm{~cm}, \mathrm{Th}=0.07 \mathrm{~cm}$

Material: Copper

Description: Copper plate fragment (fitting), probably from the same object as $\mathrm{Z}_{5} / 24$.

Cat. 54

Two wood pieces with clamps

Inv. no.: $\mathrm{Z}_{7} / 5$

Context data: Tumulus 7 , layer 5 , entrance to tunnel

Dimensions: Fr. 1: clamps: $\mathrm{L}=2 \mathrm{~cm}, \mathrm{~W}=0.4 \mathrm{~cm}, \mathrm{Th}=$ $0.05 \mathrm{~cm}$; wood: $\mathrm{L}=9.9 \mathrm{~cm}$ (long fr.) and $6.6 \mathrm{~cm}$ (short fr.), $\mathrm{Th}=0.7 \mathrm{~cm}$ 


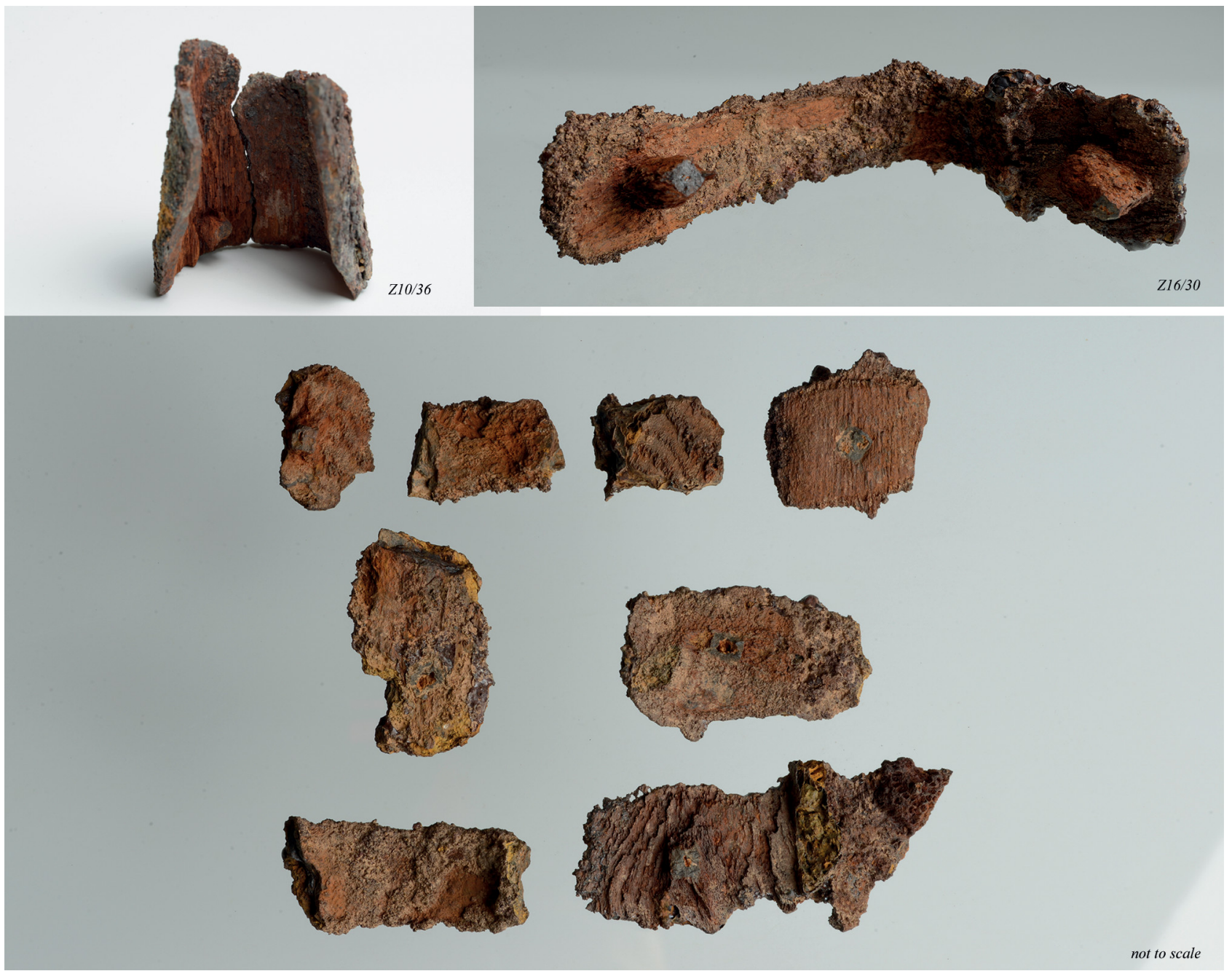

FIGURE 17.7 Wooden imprints in the metal fittings PHOTOS BY A. KAMROWSKI

Fr. 2: clamps: $\mathrm{L}=2 \mathrm{~cm}, \mathrm{~W}=0.4 \mathrm{~cm}$, $\mathrm{Th}=0.05 \mathrm{~cm}$; wood:

$\mathrm{L}=7 \mathrm{~cm}$ (long fr.) and $3 \mathrm{~cm}$ (short fr.), $\mathrm{Th}=0.7 \mathrm{~cm}$

Material: Copper and wood

Description: Two wood pieces with copper clamps.

\section{Cat. 55}

One rod fragment

Inv. no.: $\mathbf{Z} 4 / 74$

Context data: Tumulus 4, tunnel, E side

Dimensions: $\mathrm{L}=14.2 \mathrm{~cm}, \mathrm{D}=1.3 \mathrm{~cm}, 2.4 \mathrm{~cm}$, ring $\mathrm{Th}=0.9 \mathrm{~cm}$

Material: Iron

Description: Heavily corroded iron rod fragments (with hoop attached at one end).

Cat. 56

Rod fragment with clamp and broken arm (probable bolt)

Inv. no.: $\mathrm{Z}_{7} / 6$

Context data: Tumulus 7 , layer 5 , close to pillar I

Dimensions: top D $=1.1 \mathrm{~cm}$, base $\mathrm{D}=1.2 \mathrm{~cm}$, square crosssection of $\mathrm{arm}=0.8 \mathrm{~cm} \times 0.8 \mathrm{~cm}$, clamp Th $=0.9 \mathrm{~cm}$
Material: Iron

Description: Rod fragment with clamp and broken arm, probably part of the locking mechanism of a chest.

Cat. 57

Knife, reassembled from several smaller fragments (incomplete blade)

Inv. no.: $\mathrm{Z1o} / \mathbf{3 1}^{1}$

Context data: Tumulus 10, burial chamber

Dimensions: $\mathrm{a}: \mathrm{L}=3.3 \mathrm{~cm}, \mathrm{~W}=1 \mathrm{~cm}, \mathrm{Th}=1 \mathrm{~cm} ; \mathrm{b}: \mathrm{L}=9.5 \mathrm{~cm}$ (after gluing), $\mathrm{W}=1.3 \mathrm{~cm}, \mathrm{Th}=1-1.2 \mathrm{~cm} ; \mathrm{c}: \mathrm{L}=6.3 \mathrm{~cm}$, $\mathrm{W}=1-1.3 \mathrm{~cm}, \mathrm{Th}=1.2 \mathrm{~cm}$

Material and technique: Forge-welded iron

Description: Four iron rod fragments; four fragments of flared rod (1.2-1.4 cm in cross-section). 